\title{
Preparation of 2-amido substituted furans using the Curtius re- arrangement of furan-2-carbonyl azide
}

\author{
Albert Padwa* and Tianhua Wu \\ Department of Chemistry, Emory University, Atlanta, GA 30322, USA \\ E-mail: chemap@emory.edu
}

\begin{abstract}
Dedicated to Gurnos Jones on the occasion of his $70^{\text {th }}$ birthday and for his many significant contributions to heterocyclic chemistry
\end{abstract}

(received 12 Feb 00; accepted 20 Aug 00; published on the web 28 Aug 00)

\begin{abstract}
A series of 2-amido substituted furans were readily prepared from furan-2-carbonyl azide. Heating a sample of the azide in a 2:1-benzene/toluene mixture resulted in a Curtius rearrangement and the in situ generation of furanyl isocyanate. Subsequent treatment of this reactive intermediate with either a Grignard reagent or a higher order cyanocuprate furnished the desired 2-amido substituted furanyl system.
\end{abstract}

Keywords: Curtius arrangement, furan -2-carbonyl azide, 2-amidofurans

\section{Introduction}

Heterocycles such as furan, thiophene, and pyrrole undergo Diels-Alder reactions despite their stabilized $6 \pi$-aromatic electronic configuration. ${ }^{1}$ By far the most extensively studied five-ring heteroaromatic system for Diels-Alder cycloaddition is furan and its substituted derivatives. ${ }^{2}$ The resultant 7-oxabicyclo[2.2.1] heptanes are valuable synthetic intermediates that have been further elaborated to substituted arenes, carbohydrate derivatives, and various natural products. ${ }^{3-5} \mathrm{~A}$ crucial synthetic transformation employing these intermediates involves the cleavage of the oxygen bridge to produce functionalized cyclohexene derivatives. ${ }^{6,7}$ While the bimolecular Diels-Alder reaction of alkyl substituted furans has been the subject of many reports in the literature, ${ }^{8}$ much less is known regarding the cycloaddition behavior of furans that contain heteroatoms attached directly to the aromatic ring. ${ }^{9}$ In this regard, we have become interested in the Diels-Alder reaction of 2-aminofurans as a method for preparing substituted aniline derivatives since these compounds are important starting materials for the preparation of various pharmaceuticals. ${ }^{10}$ Many furan Diels-Alder reactions require high pressure or Lewis acid catalysts to give satisfactory yields of cycloadduct. ${ }^{11}$ In contrast to this situation, 2-amino-5- 
carbomethoxyfuran readily reacted with several monoactivated olefins by simply heating in benzene at $80 \mathrm{C}$. The initially formed cyclohexadienol underwent a subsequent dehydration when treated with 1 equiv of $\mathrm{BF}_{3} \mathrm{OEt}_{2}$ to give the substituted aniline derivative. ${ }^{12}$

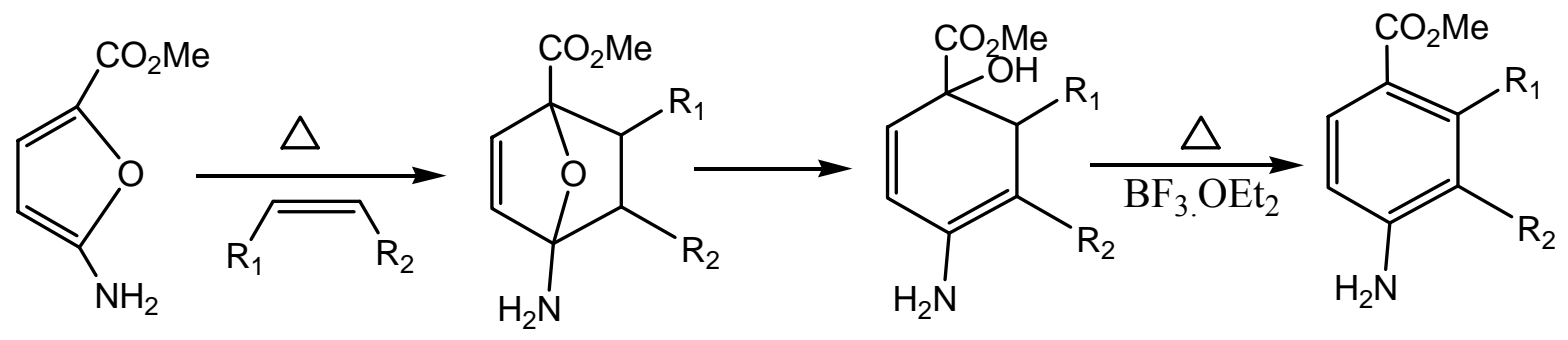

In each case, the cycloaddition proceeded with complete regioselectivity, with the electronwithdrawing group being located ortho to the amino group. The regio-chemical results are perfectly consistent with FMO theory. ${ }^{13}$ The most favorable FMO interaction is between the HOMO of the furanamine and the LUMO of the dienophile. The atomic coefficient at the ester bearing furan carbon is larger than at the amino center, and this nicely accommodates the observed regioselectivity.

The intramolecular Diels-Alder reaction of furans, often designated as IMDAF, ${ }^{14}$ helps to overcome the sluggishness of this heteroaromatic ring system toward [4]-cycloaddition. Not only do IMDAF reactions allow for the preparation of complex oxygenated polycyclic compounds, they often proceed at lower temperatures than their intermolecular counterparts. ${ }^{8}$ Even more significantly, unactivated $\pi$-bonds are often suitable dienophiles for the internal cycloaddition. Indeed, we discovered that the IMDAF reaction of a series of furanamide derivatives

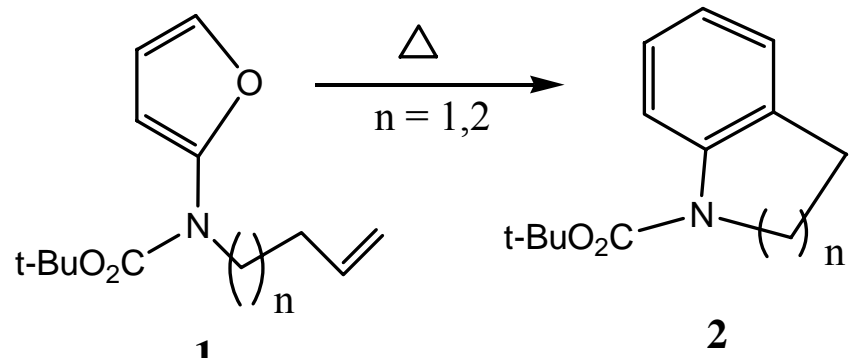

1

(i.e. 1) occurred smoothly to furnish cyclized aromatic carbamates 2 as the only isolable products in high yield. ${ }^{15}$ When the alkenyl group possesses a substituent at the 2-position of the $\pi$-bond, the thermal reaction furnished a rearranged hexahydroindolinone (i.e. 6). ${ }^{16}$ With this system, the initially formed cycloadduct 4 cannot aromatize. Instead, ring opening of the oxabicyclic intermediate occurs to generate zwitterion 5 which undergoes a subsequent proton elimination followed by tautomerization to give the rearranged ketone 6 . 


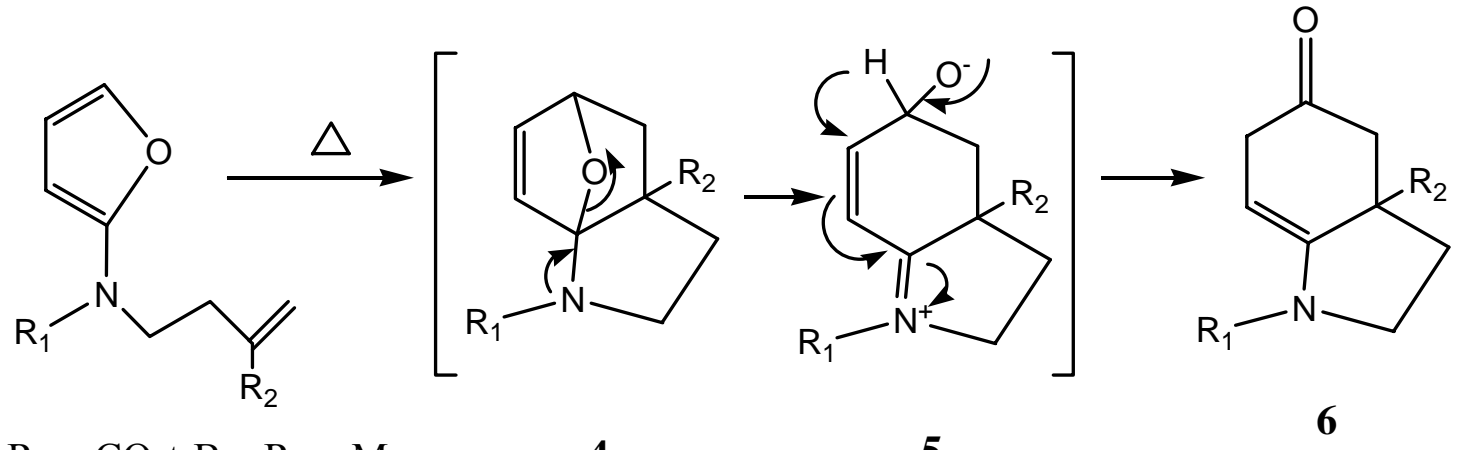

3; $\mathrm{R}_{1}=\mathrm{CO}_{2} \mathrm{t}-\mathrm{Bu} ; \mathrm{R}_{2}=\mathrm{Me}$

4

5

\section{Results and Discussion}

To further probe the cycloaddition method, we desired to study a number of related amidofurans possessing tethered alkenyl groups. The starting material used to prepare these systems was furan-2-carbonyl azide (7) which could be obtained from furoic acid using a procedure described by Edwards and Singleton in $85 \%$ yield. ${ }^{17}$ We had already demonstrated that the thermolysis of 7 in an alcohol solvent resulted in a Curtius rearrangement to give isocyanate 8 as a transient species which further reacted with the alcoholic solvent to furnish a furanyl carbamate in high yield. ${ }^{15}$ In this paper, we report on the reaction of isocyanate 8 with both Grignard and cuprate reagents to give a series of furanyl amides which represent useful substrates for further DielsAlder studies.

Our investigations began by heating a sample of furanyl acyl azide 7 in a benzene/toluene mixture at $90{ }^{\circ} \mathrm{C}$ so as to generate isocyanate 8 . After cooling to $0{ }^{\circ} \mathrm{C}$, the solution was allowed to react with several Grignard reagents. Thus, treatment of 8 with phenyl magnesium bromide afforded furan 9 in $63 \%$ yield. In a like manner, the reaction with allyl magnesium bromide gave 10 but only in $21 \%$ yield. The addition of a ortho-substituted aromatic Grignard to isocyanate 8 was also studied. 2-Vinylphenyl magnesium bromide was prepared by treating 2-bromostyrene with magnesium turnings in ether and was allowed to react with isocyanate 8 at $0{ }^{\circ} \mathrm{C}$. The only product that could be isolated corresponded to the desired amidofuran 11, but in a modest $32 \%$ yield.

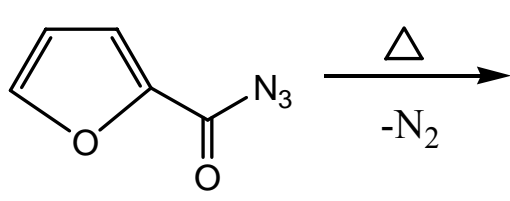

7
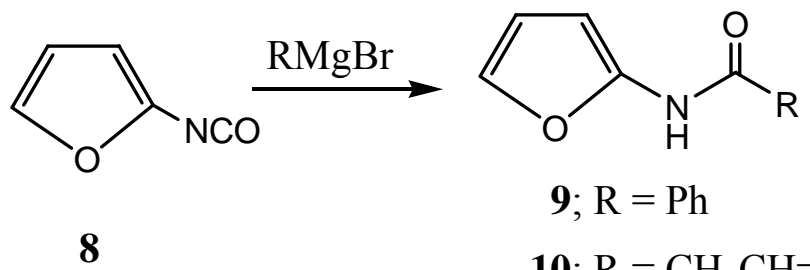

9; $\mathrm{R}=\mathrm{Ph}$

10; $\mathrm{R}=\mathrm{CH}_{2} \mathrm{CH}=\mathrm{CH}_{2}$

11; $\mathrm{R}=2-\left(\mathrm{CH}_{2}=\mathrm{CHC}_{6} \mathrm{H}_{4}\right)$ 
So that a cross-section of additional information could be obtained regarding the trapping of furanyl isocyanate 8 with other organometallic reagents, we investigated its reaction with a series of alkyl cuprates. Exposure of a freshly prepared solution of 8 to methyl cuprate in ether at $0{ }^{\circ} \mathrm{C}$ furnished amide 12 in $60 \%$ yield. Similarly, the reaction of 8 with $n$-butyl, sec-butyl and $t$-butyl cuprates gave furanyl amides 13,14 and 15 in $60 \%, 54 \%$ and $45 \%$ yield, thereby demonstrating that cuprate reagents can also be used as effective nucleophiles in these trapping reactions. Hex4-enoic acid furan-2-ylamide (16) was also prepared (42\%) from isocyanate 8 and the cuprate derived from trans1-iodo-3-pentene.Finally, treatment of acyl azide 7 with the $t$-butyl copper lithium reagent also proceeded very smoothly to give the isomeric furanyl amide 17 in $78 \%$ isolated yield.

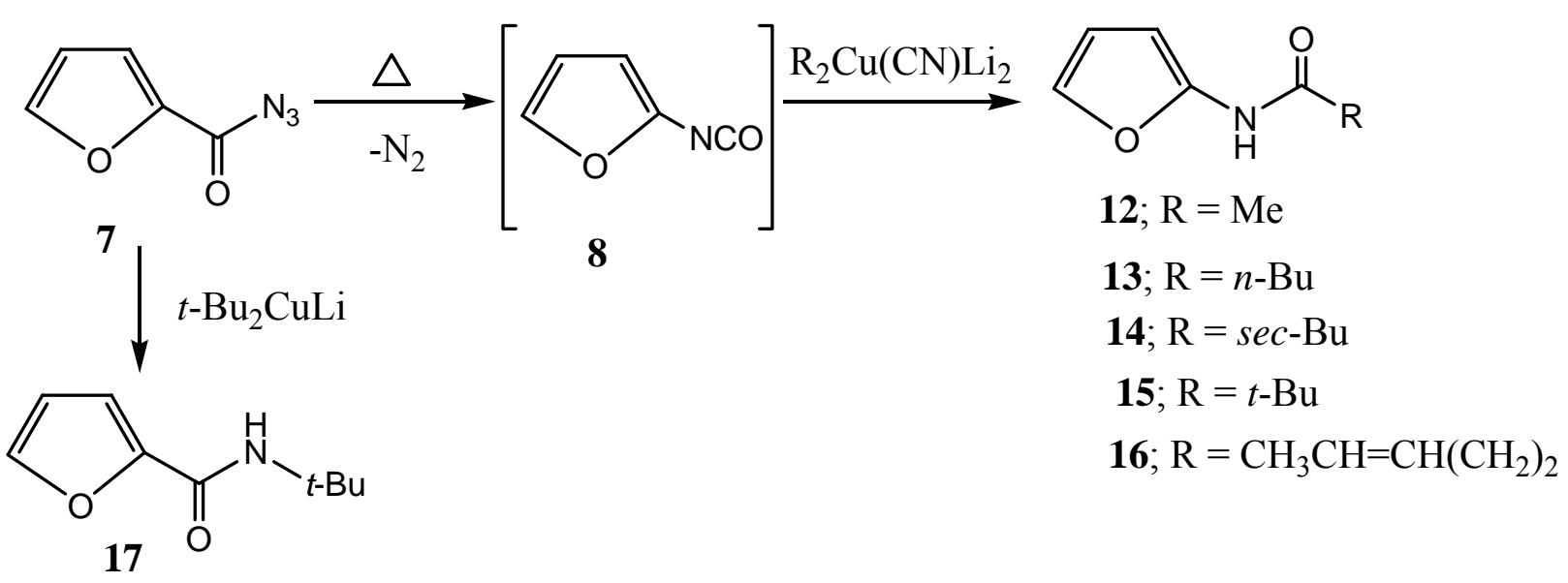

In conclusion, the synthetic procedure described herein provides a simple and general approach for the construction of various furanyl amides which, in certain cases, contain unsaturation on the side chain. We are currently investigating their thermal Diels-Alder behavior and hope to apply the [4]-cycloaddition-rearrange-ment sequence toward the synthesis of several complex octahydroindole-based alkaloids.

\section{Experimental Section}

General Procedures. Melting points are uncorrected. Mass spectra were determined at an ionizing voltage of $70 \mathrm{eV}$. Unless otherwise noted, all reactions were performed in flame dried glassware under an atmosphere of dry argon. Solutions were evaporated under reduced pressure with a rotary evaporator and the residue was chromatographed on a silica gel column using an ethyl acetate/hexane mixture as the eluent unless specified otherwise. All solids were recrystallized from ethyl acetate/hexane for analytical data. 
Furan-2-carbonyl azide (7). To a solution containing $67.8 \mathrm{~g}(0.60 \mathrm{~mol})$ of 2 -furoic acid in $500 \mathrm{~mL}$ of benzene was added $66 \mathrm{~mL}(0.9 \mathrm{~mol})$ of thionyl chloride. The mixture was heated at reflux for $18 \mathrm{~h}$. After concentration under reduced pressure, the residue was distilled under water aspirator to give $67.5 \mathrm{~g}(86 \%)$ of furan-2-carbonyl chloride ${ }^{18}\left(\mathrm{bp} 79^{\circ} \mathrm{C}(35 \mathrm{~mm})\right)$ as a colorless liquid; ${ }^{1} \mathrm{H}-\mathrm{NMR}\left(\mathrm{CDCl}_{3}, 400 \mathrm{MHz}\right) \delta 6.65(\mathrm{dd}, 1 \mathrm{H}, J=3.8$ and $1.6 \mathrm{~Hz}), 7.50(\mathrm{dd}, 1 \mathrm{H}, J=3.8$ and $0.8 \mathrm{~Hz}$ ), and $7.76(\mathrm{dd}, 1 \mathrm{H}, J=1.6$ and $0.8 \mathrm{~Hz})$.

To a solution of $66.6 \mathrm{~g}(0.5 \mathrm{~mol})$ of the above acid chloride in $200 \mathrm{~mL}$ of ether at $0{ }^{\circ} \mathrm{C}$ was added dropwise a solution containing $33 \mathrm{~g}(0.5 \mathrm{~mol})$ of sodium azide in $150 \mathrm{~mL}$ of water. The mixture was stirred at $0{ }^{\circ} \mathrm{C}$ for $15 \mathrm{~min}$, then warmed to $\mathrm{rt}$ and stirred for another $2 \mathrm{~h}$. After removal of the ether under reduced pressure, the resulting suspension was filtered and washed with cold water. The resulting white solid that formed was dried under vacuum to give $68.3 \mathrm{~g} \mathrm{(98 \% )}$ of furan-2carbonyl azide (7); ${ }^{17}$ IR (neat) 3134, 2145, 1690, and $1292 \mathrm{~cm}^{-1} ;{ }^{1} \mathrm{H}-\mathrm{NMR}\left(\mathrm{CDCl}_{3}, 300 \mathrm{MHz}\right) \delta$ $6.56(\mathrm{dd}, 1 \mathrm{H}, J=3.6$ and $2.4 \mathrm{~Hz}), 7.27(\mathrm{~d}, 1 \mathrm{H}, J=2.4 \mathrm{~Hz})$, and $7.66(\mathrm{~d}, 1 \mathrm{H}, J=3.6 \mathrm{~Hz}) ;{ }^{13} \mathrm{C}-$ NMR $\left(\mathrm{CDCl}_{3}, 75 \mathrm{MHz}\right) \delta 112.6,120.1,145.6,148.2$, and 162.5; Anal. Calcd for $\mathrm{C}_{5} \mathrm{H}_{3} \mathrm{~N}_{3} \mathrm{O}_{2}$ : C, 43.80; H, 2.21; N, 30.65. Found: C, 43.62; H, 2.18; N, 30.76.

$\boldsymbol{N}$-Furan-2-yl-benzamide (9). A solution of $0.35 \mathrm{~g}(2.6 \mathrm{mmol})$ of azide 7 in $30 \mathrm{~mL}$ of $2: 1$ benzene-toluene mixture was heated at reflux for $2 \mathrm{~h}$. To the resulting solution at $0{ }^{\circ} \mathrm{C}$ was added $0.9 \mathrm{~mL}(2.6 \mathrm{mmol})$ of a $3.0 \mathrm{M}$ phenyl magnesium bromide solution dropwise. After the addition was complete, the mixture was stirred at $\mathrm{rt}$ for $1 \mathrm{~h}$, quenched with a saturated $\mathrm{NH}_{4} \mathrm{Cl}$ solution, extracted with ether, and dried over $\mathrm{Na}_{2} \mathrm{SO}_{4}$. Removal of the solvent under reduced pressure followed by flash silica gel chromatography gave $0.3 \mathrm{~g}(63 \%)$ of $N$-furan-2-yl-benzamide (9) ${ }^{18}$ as a pale yellow solid: mp 121-122 ${ }^{\circ} \mathrm{C} ;{ }^{1} \mathrm{H}-\mathrm{NMR}\left(\mathrm{CDCl}_{3}, 400 \mathrm{MHz}\right) \delta 6.35(\mathrm{~m}, 1 \mathrm{H}), 6.42(\mathrm{~d}, 1 \mathrm{H}, J$ $=2.8 \mathrm{~Hz}), 7.02(\mathrm{~m}, 1 \mathrm{H}), 7.37(\mathrm{t}, 2 \mathrm{H}, J=6.8 \mathrm{~Hz}), 7.45(\mathrm{~m}, 1 \mathrm{H}), 7.82(\mathrm{~m}, 1 \mathrm{H})$, and $8.90(\mathrm{brs}, 1 \mathrm{H})$; ${ }^{13} \mathrm{C}-\mathrm{NMR}\left(\mathrm{CDCl}_{3}, 100 \mathrm{MHz}\right) \delta$ 95.7, 111.4, 127.2, 128.5, 132.0, 133.1, 135.5, 145.4, and 164.0; Anal. Calcd for $\mathrm{C}_{11} \mathrm{H}_{9} \mathrm{NO}_{2}$ : C, 70.58; H, 4.85; N, 7.48. Found: C, 70.56; H, 4.91; N, 7.51.

But-3-enoic acid furan-2-yl-amide (10). A solution of $1.0 \mathrm{~g}(7.6 \mathrm{mmol})$ of azide 7 in $60 \mathrm{~mL}$ of a 2:1 benzene-toluene mixture was heated at reflux for $2 \mathrm{~h}$. To the resulting dark solution at $0{ }^{\circ} \mathrm{C}$ was added $7 \mathrm{~mL}(7.6 \mathrm{mmol})$ of a $1.1 \mathrm{M}$ allyl magnesium bromide solution dropwise. After the addition was complete, the mixture was stirred at $\mathrm{rt}$ for $1 \mathrm{~h}$, quenched with a saturated $\mathrm{NH}_{4} \mathrm{Cl}$ solution, extracted with ether, and dried over $\mathrm{Na}_{2} \mathrm{SO}_{4}$. Removal of the solvent under reduced pressure followed by flash silica gel chromatography gave $0.24 \mathrm{~g}(21 \%)$ of but-3-enoic acid furan-2-yl amide(10)as a pale yellow solid: $\mathrm{mp} 67-70{ }^{\circ} \mathrm{C}$; IR (KBr) 3196, 3040, 1658, and 1582 $\mathrm{cm}^{-1} ;{ }^{1} \mathrm{H}-\mathrm{NMR}\left(\mathrm{CDCl}_{3}, 400 \mathrm{MHz}\right) \delta 3.18(\mathrm{~d}, 2 \mathrm{H}, J=7.2 \mathrm{~Hz}), 5.32-5.37$ (m, 2H), 5.97-6.04 (m, $1 \mathrm{H}), 6.32(\mathrm{~d}, 1 \mathrm{H}, J=3.2 \mathrm{~Hz}), 6.37(\mathrm{dd}, 1 \mathrm{H}, J=3.2$ and $2.0 \mathrm{~Hz}), 7.05(\mathrm{dd}, 1 \mathrm{H}, J=2.0$ and 1.0 $\mathrm{Hz}$ ), and 7.60 (brs, $1 \mathrm{H}) ;{ }^{13} \mathrm{C}-\mathrm{NMR}\left(\mathrm{CDCl}_{3}, 100 \mathrm{MHz}\right) \delta 41.5,95.5,111.4,120.7,130.4,135.4$, 145.0, and 167.2; Anal. Calcd for $\mathrm{C}_{8} \mathrm{H}_{9} \mathrm{NO}_{2}$ : C, 63.57; H, 6.00; N, 9.27. Found: C, 63.47; H, $6.05 ; \mathrm{N}, 9.21$.

$N$-Furan-2-yl-2-vinyl-benzamide (11). To a suspension of $0.15 \mathrm{~g}(6.2 \mathrm{mmol})$ of magnesium turnings in $10 \mathrm{~mL}$ of ether at $\mathrm{rt}$ was added dropwise $0.5 \mathrm{~mL}(4.0 \mathrm{mmol})$ of 2-bromostyrene and one drop of 1,2-diiodoethane. The mixture was heated at reflux for $30 \mathrm{~min}$ and then stirred at $\mathrm{rt}$ 
for $18 \mathrm{~h}$. The suspension was filtered through a pad of glass wool and the resulting 2-vinylphenyl magnesium bromide was used directly in the next step. A solution of $0.5 \mathrm{~g}$ (4.0 mmol) of azide 7 in $40 \mathrm{~mL}$ of a $2: 1$ benzene-toluene mixture was heated at reflux for $2 \mathrm{~h}$. The resulting dark solution was cooled to $0{ }^{\circ} \mathrm{C}$ and cannulated into the above Grignard reagent solution at $0{ }^{\circ} \mathrm{C}$. The mixture was warmed to rt, stirred for $1 \mathrm{~h}$, diluted with ether, quenched with an aqueous $\mathrm{NH}_{4} \mathrm{Cl}$ solution, extracted with ether, and dried over $\mathrm{Na}_{2} \mathrm{SO}_{4}$. Removal of the solvent under reduced pressure followed by flash silica gel chromatography gave $0.27 \mathrm{~g}(32 \%)$ of $N$-furan-2-yl-2-vinylbenzamide (11) as a pale yellow solid: $\mathrm{mp} 92-93{ }^{\circ} \mathrm{C}$; IR $(\mathrm{KBr}) 3241,1656$, and $1551 \mathrm{~cm}^{-1}$; ${ }^{1} \mathrm{H}-$ $\operatorname{NMR}\left(\mathrm{CDCl}_{3}, 400 \mathrm{MHz}\right) \delta 5.40(\mathrm{~d}, 1 \mathrm{H}, J=11.2 \mathrm{~Hz}), 5.73(\mathrm{dd}, 1 \mathrm{H}, J=9.4$ and $1.0 \mathrm{~Hz}), 6.41(\mathrm{t}$, $1 \mathrm{H}, J=2.4 \mathrm{~Hz}), 6.46(\mathrm{~d}, 1 \mathrm{H}, J=3.2 \mathrm{~Hz}), 7.05-7.12(\mathrm{~m}, 2 \mathrm{H}), 7.30(\mathrm{t}, 1 \mathrm{H}, J=7.6 \mathrm{~Hz}), 7.43(\mathrm{t}, 1 \mathrm{H}$, $J=7.4 \mathrm{~Hz}), 7.52-7.58(\mathrm{~m}, 2 \mathrm{H})$, and 8.16 (brs, $1 \mathrm{H}) ;{ }^{13} \mathrm{C}-\mathrm{NMR}\left(\mathrm{CDCl}_{3}, 100 \mathrm{MHz}\right) \delta$ 95.3, 111.5, 117.6, 126.7, 127.6, 127.8, 130.9, 133.5, 134.3, 135.4, 136.4, 145.2, and 164.9; Anal. Calcd for $\mathrm{C}_{13} \mathrm{H}_{11} \mathrm{NO}_{2}$ : C, 73.23; H, 5.20; N, 6.57. Found: C, 73.48; H, 5.25; N, 6.52.

$\mathrm{N}$-Furan-2-yl-acetamide (12). To a suspension of $0.25 \mathrm{~g}(2.8 \mathrm{mmol})$ of $\mathrm{CuCN}$ in $10 \mathrm{~mL}$ of THF at $-78{ }^{\circ} \mathrm{C}$ was added dropwise $4.0 \mathrm{~mL}(5.5 \mathrm{mmol})$ of a $1.4 \mathrm{M}$ methyl lithium solution and themixture was stirred at $-78{ }^{\circ} \mathrm{C}$ for $40 \mathrm{~min}$. A solution of $0.4 \mathrm{~g}(2.8 \mathrm{mmol})$ of azide 7 in a mixture of $20 \mathrm{~mL}$ of benzene and $10 \mathrm{~mL}$ of toluene was heated at reflux for $2 \mathrm{~h}$. The resulting dark solution was cooled to $0{ }^{\circ} \mathrm{C}$ and cannulated into the above cuprate solution. The mixture was warmed to rt, stirred for $1 \mathrm{~h}$, diluted with ether, quenched with an aqueous $\mathrm{NH}_{4} \mathrm{Cl}$ solution, and extracted with ether. The organic layer was dried over $\mathrm{Na}_{2} \mathrm{SO}_{4}$ and the solvent was evaporated under reduced pressure. The residue was subjected to flash silica gel chromatography to give $0.2 \mathrm{~g}(60 \%)$ of $N$-furan-2-yl-acetamide (12) as a white solid ${ }^{19}: \mathrm{mp} 92-94{ }^{0} \mathrm{C}$; IR (KBr) 3196, 3033, and $1660 \mathrm{~cm}^{-1} ;{ }^{1} \mathrm{H}-\mathrm{NMR}\left(\mathrm{CDCl}_{3}, 400 \mathrm{MHz}\right) \delta 2.17(\mathrm{~s}, 3 \mathrm{H}), 6.29-6.36(\mathrm{~m}, 2 \mathrm{H}), 7.05$ $(\mathrm{t}, 1 \mathrm{H}, J=2.0 \mathrm{~Hz})$, and $7.90(\mathrm{brs}, 1 \mathrm{H}) ;{ }^{13} \mathrm{C}-\mathrm{NMR}\left(\mathrm{CDCl}_{3}, 100 \mathrm{MHz}\right) \delta 23.3,103.6,111.4,135.4$, 145.2, and 167.0; Anal. Calcd for $\mathrm{C}_{6} \mathrm{H}_{7} \mathrm{NO}_{2}$ : C, 57.59; H, 5.64; N, 11.19. Found: C, 57.60; H, $5.61 ; \mathrm{N}, 11.29$.

Pentanoic acid furan-2-ylamide (13). To a suspension of $0.25 \mathrm{~g}(2.8 \mathrm{mmol})$ of $\mathrm{CuCN}$ in $6 \mathrm{~mL}$ of THF at $-78{ }^{\circ} \mathrm{C}$ was added dropwise $2.2 \mathrm{~mL}(5.5 \mathrm{mmol})$ of a $2.5 \mathrm{M} \mathrm{n}$-BuLi solution and the mixture was stirred at $-78{ }^{\circ} \mathrm{C}$ for $1 \mathrm{~h}$. A solution of $0.4 \mathrm{~g}(2.8 \mathrm{mmol})$ of azide 7 in a mixture of $16 \mathrm{~mL}$ of benzene and $8 \mathrm{~mL}$ of toluene was heated at reflux for $2 \mathrm{~h}$. The resulting dark solution was cooled to $-5{ }^{\circ} \mathrm{C}$ and cannulated into the above cuprate solution. The mixture was warmed to $\mathrm{rt}$, stirred for $1 \mathrm{~h}$, diluted with ether, quenched with an aqueous $\mathrm{NH}_{4} \mathrm{Cl}$ solution, and extracted with ether. The organic layer was dried over $\mathrm{Na}_{2} \mathrm{SO}_{4}$ and the solvent was evaporated under reduced pressure. The residue was subjected to flash silica gel chromatography to give $0.28 \mathrm{~g}$ $(60 \%)$ of pentanoic acid furan-2-ylamide (13) as a pale yellow solid: mp $87-89{ }^{\circ} \mathrm{C}$; IR $(\mathrm{KBr})$ 3253, 1666, and $1554 \mathrm{~cm}^{-1} ;{ }^{1} \mathrm{H}-\mathrm{NMR}\left(\mathrm{CDCl}_{3}, 400 \mathrm{MHz}\right) \delta 0.92(\mathrm{t}, 3 \mathrm{H}, J=7.4 \mathrm{~Hz}), 1.38(\mathrm{~m}$, 2H), $1.69(\mathrm{~m}, 2 \mathrm{H}), 2.37(\mathrm{t}, 2 \mathrm{H}, J=7.6 \mathrm{~Hz}), 6.29(\mathrm{~d}, 1 \mathrm{H}, J=3.2 \mathrm{~Hz}), 6.35(\mathrm{~m}, 1 \mathrm{H}), 7.02(\mathrm{~s}, 1 \mathrm{H})$, and 8.34 (brs, $1 \mathrm{H}) ;{ }^{13} \mathrm{C}-\mathrm{NMR}\left(\mathrm{CDCl}_{3}, 100 \mathrm{MHz}\right) \delta 13.7,22.3,27.5,36.3,95.2,111.3,135.1$, 145.3, and 170.1; HRMS Calcd for $\mathrm{C}_{9} \mathrm{H}_{13} \mathrm{NO}_{2}$ : 167.0946. Found: 167.0943. 
$\mathrm{N}$-Furan-2-yl-2-methyl-butyramide (14). To a suspension of $0.25 \mathrm{~g}(2.8 \mathrm{mmol})$ of $\mathrm{CuCN}$ in $7 \mathrm{~mL}$ of THF at $-78{ }^{\circ} \mathrm{C}$ was added dropwise $4.3 \mathrm{~mL}(5.6 \mathrm{mmol})$ of a $1.3 \mathrm{M} \mathrm{sec}$-BuLi solution and the mixture was stirred at $-78{ }^{\circ} \mathrm{C}$ for $1 \mathrm{~h}$. A solution of $0.38 \mathrm{~g}(2.8 \mathrm{mmol})$ of azide 7 in a mixture of $20 \mathrm{~mL}$ of benzene and $10 \mathrm{~mL}$ of toluene was heated at reflux for $2 \mathrm{~h}$. The resulting dark solution was cooled to $-5{ }^{\circ} \mathrm{C}$ and cannulated into the above cuprate solution. The mixture was warmed to rt, stirred for $1 \mathrm{~h}$, diluted with ether, quenched with an aqueous $\mathrm{NH}_{4} \mathrm{Cl}$ solution, and extracted with ether. The organic layer was dried over $\mathrm{Na}_{2} \mathrm{SO}_{4}$ and the solvent was evaporated under reduced pressure. The residue was subjected to flash silica gel chromatography to give $0.25 \mathrm{~g}(54 \%)$ of $N$-furan-2-yl-2-methyl-butyramide (14) as a white solid: mp $85-86{ }^{\circ} \mathrm{C}$; IR (KBr) 3260, 1671, 1651, and $1555 \mathrm{~cm}^{-1}$; ${ }^{1} \mathrm{H}-\mathrm{NMR}\left(\mathrm{CDCl}_{3}, 400 \mathrm{MHz}\right) \delta 0.96(\mathrm{t}, 3 \mathrm{H}, J=7.4 \mathrm{~Hz}), 1.23$ $(\mathrm{d}, 3 \mathrm{H}, J=7.2 \mathrm{~Hz}), 1.47-1.58(\mathrm{~m}, 1 \mathrm{H}), 1.72-1.82(\mathrm{~m}, 1 \mathrm{H}), 2.23-2.32(\mathrm{~m}, 1 \mathrm{H}), 6.33-6.34(\mathrm{~m}, 1 \mathrm{H})$, $6.38(\mathrm{t}, 1 \mathrm{H}, J=2.6 \mathrm{~Hz}), 7.04(\mathrm{t}, 1 \mathrm{H}, J=1.0 \mathrm{~Hz})$, and $7.49(\mathrm{brs}, 1 \mathrm{H}) ;{ }^{13} \mathrm{C}-\mathrm{NMR}\left(\mathrm{CDCl}_{3}, 100\right.$ $\mathrm{MHz}) \delta 11.8,17.3,27.3,43.2,95.0,111.5,135.1,145.2$, and 172.8; HRMS Calcd for $\mathrm{C}_{9} \mathrm{H}_{13} \mathrm{NO}_{2}$ : 167.0946. Found: 167.0943.

$\boldsymbol{N}$-Furan-2-yl-2,2-dimethyl-propionamide (15). To a suspension of $0.25 \mathrm{~g}(2.8 \mathrm{mmol})$ of $\mathrm{CuCN}$ in $7 \mathrm{~mL}$ of $\mathrm{THF}$ at $-78{ }^{\circ} \mathrm{C}$, was added dropwise $3.7 \mathrm{~mL}(5.6 \mathrm{mmol})$ of a $1.5 \mathrm{M} t$-BuLi solution and the mixture was stirred at $-78{ }^{\circ} \mathrm{C}$ for $1 \mathrm{~h}$. A solution of $0.38 \mathrm{~g}(2.8 \mathrm{mmol})$ of azide 7 in a mixture of $20 \mathrm{~mL}$ of benzene and $10 \mathrm{~mL}$ of toluene was heated at reflux for $2 \mathrm{~h}$. The resulting dark solution was cooled to $-5{ }^{\circ} \mathrm{C}$ and cannulated into the above cuprate solution. The mixture was warmed to rt, stirred for $1 \mathrm{~h}$, diluted with ether, quenched with an aqueous $\mathrm{NH}_{4} \mathrm{Cl}$ solution, and extracted with ether. The organic layer was dried over $\mathrm{Na}_{2} \mathrm{SO}_{4}$ and the solvent was removed under reduced pressure. The residue was subjected to flash silica gel chromatography to give $0.21 \mathrm{~g}(45 \%)$ of $N$-furan-2-yl-2,2-dimethyl-propionamide (15) as a white solid: mp 101$102{ }^{\circ} \mathrm{C}$; IR (KBr) 3274, 1663, and $1529 \mathrm{~cm}^{-1}$; ${ }^{1} \mathrm{H}-\mathrm{NMR}\left(\mathrm{CDCl}_{3}, 400 \mathrm{MHz}\right) \delta 1.30(\mathrm{~s}, 9 \mathrm{H}), 6.32-$ $6.34(\mathrm{~m}, 1 \mathrm{H}), 6.37-6.38(\mathrm{~m}, 1 \mathrm{H}), 7.04-7.05(\mathrm{~m}, 1 \mathrm{H})$, and $7.70(\mathrm{brs}, 1 \mathrm{H}) ;{ }^{13} \mathrm{C}-\mathrm{NMR}\left(\mathrm{CDCl}_{3}, 100\right.$ $\mathrm{MHz}) \delta 27.5,39.2,94.7,111.6,135.0,145.5$, and 174.5; Anal. Calcd for $\mathrm{C}_{9} \mathrm{H}_{13} \mathrm{NO}_{2}$ : C, 64.65; $\mathrm{H}$, 7.84; N, 8.38. Found: C, 64.47; H, 7.78; N, 8.27.

Hex-4-enoic acid furan-2-ylamide (16). To a solution containing $1.2 \mathrm{~g}(6.1 \mathrm{mmol})$ of trans-1iodo-3-pentene in $10 \mathrm{~mL}$ of ether at $-78^{\circ} \mathrm{C}$ was added dropwise $8.1 \mathrm{~mL}(12 \mathrm{mmol})$ of a $1.5 \mathrm{M} \mathrm{t}$ BuLi solution. The mixture was stirred at $-78{ }^{\circ} \mathrm{C}$ for $30 \mathrm{~min}$, warmed to $\mathrm{rt}$, and cannulated through a pad of glass wool into a suspension containing $0.25 \mathrm{~g}(2.8 \mathrm{mmol})$ of $\mathrm{CuCN}$ in $6 \mathrm{~mL}$ of THF at $-78{ }^{\circ} \mathrm{C}$. The mixture was stirred at $-78{ }^{\circ} \mathrm{C}$ for $1 \mathrm{~h}$. A solution of $0.38 \mathrm{~g}$ (2.8 mmol) of azide 7 in a mixture of $20 \mathrm{~mL}$ of benzene and $10 \mathrm{~mL}$ of toluene was heated at reflux for $2 \mathrm{~h}$. The resulting dark solution was cooled to $0{ }^{\circ} \mathrm{C}$ and cannulated into the above cuprate solution. After stirring at $\mathrm{rt}$ for $1 \mathrm{~h}$, the mixture was diluted with ether, quenched with an aqueous $\mathrm{NH}_{4} \mathrm{Cl}$ solution, and extracted with ether. The organic layer was dried over $\mathrm{Na}_{2} \mathrm{SO}_{4}$ and the solvent was evaporated under reduced pressure. The residue was subjected to flash silica gel chromatography to give $0.21 \mathrm{~g} \mathrm{(42 \% )}$ of hex-4-enoic acid furan-2-ylamide (16) as a white solid: $\mathrm{mp}$ 65-66 ${ }^{\circ} \mathrm{C}$; IR (KBr) 3203, 3063, 1667, and $1560 \mathrm{~cm}^{-1}$; ${ }^{1} \mathrm{H}-\mathrm{NMR}\left(\mathrm{CDCl}_{3}, 400 \mathrm{MHz}\right) \delta 1.66(\mathrm{~d}, 3 \mathrm{H}, J=6.0 \mathrm{~Hz})$, 2.41 (brs, 4H), 5.44-5.55 (m, 2H), 6.31 (d, 1H, $J=3.2 \mathrm{~Hz}), 6.34(\mathrm{~m}, 1 \mathrm{H}), 7.04$ (d, 1H, $J=0.8$ 
$\mathrm{Hz}$ ), and 7.61 (brs, $1 \mathrm{H}) ;{ }^{13} \mathrm{C}-\mathrm{NMR}\left(\mathrm{CDCl}_{3}, 100 \mathrm{MHz}\right) \delta 17.9,28.2,36.5,95.2,111.5,127.0$, 129.0, 135.2, 145.0, and 168.8; Anal. Calcd for $\mathrm{C}_{10} \mathrm{H}_{13} \mathrm{NO}_{2}$ : C, 67.02; H, 7.31; N, 7.82. Found: C, 67.30; H, 7.32; N, 7.68.

Furan-2-carboxylic acid tert-butylamide (17). To a suspension of $0.25 \mathrm{~g}(2.8 \mathrm{mmol})$ of $\mathrm{CuCN}$ in $7 \mathrm{~mL}$ of THF at $-78{ }^{\circ} \mathrm{C}$ was added dropwise $3.7 \mathrm{~mL}(5.6 \mathrm{mmol})$ of a $1.5 \mathrm{M} \mathrm{t}$-BuLi solution and the mixture was stirred at $-78{ }^{\circ} \mathrm{C}$ for $1 \mathrm{~h}$. To the above solution was added dropwise a solution containing $0.38 \mathrm{~g}$ ( $2.8 \mathrm{mmol})$ of azide 7 in $15 \mathrm{~mL}$ of THF. The mixture was warmed to rt, diluted with ether, quenched with aqueous $\mathrm{NH}_{4} \mathrm{Cl}$ solution, and extracted with ether. The organic layer was dried over $\mathrm{Na}_{2} \mathrm{SO}_{4}$ and the solvent was evaporated under reduced pressure. The residue was subjected to flash silica gel chromatography to give $0.36 \mathrm{~g}(78 \%)$ of furan-2-carboxylic acid tertbutylamide (17) as a white solid ${ }^{20}$ : $\mathrm{mp} 97-98{ }^{\circ} \mathrm{C}$; IR (KBr) 3317, 1644, and $1537 \mathrm{~cm}^{-1}$; ${ }^{1} \mathrm{H}-\mathrm{NMR}$ $\left(\mathrm{CDCl}_{3}, 400 \mathrm{MHz}\right) \delta 1.46(\mathrm{~s}, 9 \mathrm{H}), 6.20(\mathrm{brs}, 1 \mathrm{H}), 6.47(\mathrm{dd}, 1 \mathrm{H}, J=3.4$ and $1.8 \mathrm{~Hz}), 7.05$ (dd, $1 \mathrm{H}, J=3.4$ and $1.0 \mathrm{~Hz})$, and $7.39(\mathrm{dd}, 1 \mathrm{H}, J=1.8$ and $1.0 \mathrm{~Hz}) ;{ }^{13} \mathrm{C}-\mathrm{NMR}\left(\mathrm{CDCl}_{3}, 100 \mathrm{MHz}\right) \delta$ 28.9, 51.4, 112.0, 113.4, 143.2, 148.7, and 157.7; Anal. Calcd for $\mathrm{C}_{9} \mathrm{H}_{13} \mathrm{NO}_{2}$ : C, 64.65; H, 7.84; N, 8.38. Found: C, 64.56; H, 7.90; N, 8.38.

\section{Acknowledgements}

We gratefully acknowledge the National Institutes of Health (GM-59384-20) for generous support of this work.

\section{References}

1. Lipshutz, B. H. Chem. Rev. 1986, 86, 795.

2. Sargent, M. V.; Dean, F. M. Furan and their Benzo Derivatives In Comprehensive Heterocyclic Chemistry; Bird, C. W.; Cheesman, G. W. H., Eds; Pergamon Press: London, 1984; Vol. 4, p 599.

3. (a) Vogel, P.; Fattori, D.; Gasparini, F.; Le Drian, C. Synlett 1990, 173. (b) Reymond, J. L.; Pinkerton, A. A.; Vogel, P. J. Org. Chem. 1991, 56, 2128.

4. Renaud, P.; Vionnet, J. -P. J. Org. Chem. 1993, 58, 5895.

5. Cox, P. J.; Simpkins, N. S. Synlett 1991, 321.

6. (a) Le Drian, C.; Vieira, E.; Vogel, P. Helv.Chem.Acta 1989, 72, 338. (b) Takahashi, T.; Iyobe, A.; Arai, Y.; Koizumi, T. Synthesis 1989, 189. (c) Guilford, A. J.; Turner, R. W. J. Chem. Soc., Chem. Commun. 1983, 466. (d) Yang, W.; Koreeda, M. J. Org. Chem. 1992, 57, 3836.

7. (a) Suami, T. Pure Appl. Chem. 1987, 59, 1509. (b) Harwood, L. M.; Jackson, B.; Prout, K.; Witt, F. J. Tetrahedron Lett. 1990, 31, 1885. (c) Koreeda, M.; Jung, K. Y.; Hirota, M. J. Am. Chem. Soc. 1990, 112, 7413. (d) Reynard, E.; Reymond, J. L.; Vogel, P. Synlett 1991, 469. 
(e) Ogawa, S.; Yoshikawa, M.; Taki, T. J. Chem. Soc., Chem. Commun. 1992, 406. (f) Ogawa, S.; Tsunoda, H. Liebigs Ann. Chem. 1992, 637.

8. Rappe, C. O.; Murphree, S. S.; Padwa, A. Tetrahedron 1997, 53, 14179.

9. (a) Gewald, K. Chem. Ber. 1966, 99, 1002. (b) Boyd, G. V.; Heatherington, K. J. Chem. Soc., Perkin Trans. 1 1973, 2523. (c) Nixon, W. J., Jr.; Garland, J. T.; DeWitt-Blanton, C., Jr. Synthesis 1980, 56. (d) Aran, V. J.; Soto, J. L. Synthesis 1982, 513. (e) Semmelhack, M. F.; Park, J. Organometallics 1986, 5, 2550. (f) Chatani, N.; Hanafusa, T. J. Org. Chem. 1987, 52, 4408. (g) Cutler, S. J.; El-Kabbani, F.; Keane, C.; Fisher-Shore, S. L.; DewittBlanton, C., Jr. Heterocycles 1990, 31, 651.

10. Wulfman, D. S. In The Chemistry of Diazonium and Diazo Groups; Patai, S., Ed.; Wiley: New York, 1978; Part 1, p 286.

11. Matsumoto, K.; Sera, A. Synthesis 1985, 999.

12. Padwa, A.; Dimitroff, M.; Waterson, A. G.; Wu, T. J. Org. Chem. 1997, 62, 4088.

13. Fleming, I. Frontier Orbitals and Organic Chemical Reactions; Wiley-Interscience: New York, 1976.

14. (a) Sternbach, D. D.; Rossana, D. M.; Onan, K. D. J. Org. Chem. 1984, 49, 3427. (b) Jung, M. E.; Gervey, J. J. Am. Chem. Soc 1989, 111, 5469. (c) Klein, L. L. J. Org. Chem. 1985, 50, 1770.

15. Padwa, A.; Dimitroff, M.; Waterson, A. G.; Wu, T. J. Org. Chem. 1998, 63, 3986.

16. Padwa, A.; Brodney, M. A.; Dimitroff, M. J. Org. Chem. 1998, 63, 5304.

17. Edwards, W.; Singleton, H. J. Am. Chem. Soc. 1938, 60, 540.

18. Devitt, P.; Timothy, A.; Vickars, M. J. Org. Chem. 1961, 26, 4941.

19. Ramsden, C. A.; Rose, H. L. J. Chem. Soc. Perkin I, 1997, 16, 2319.

20. Carpenter, A. J.; Chadwick, D. J. J. Org. Chem. 1985, 50, 4362. 